and old age, reduction in the fat content of the body seems to be entirely physiological. There have not been many published reports of the body composition of elderly people (Behnke, I963; Krzywicki \& Chinn, 1967; Montoye, Epstein \& Kjelsberg, 1965; Parizkova \& Eiselt, 1966; Young, Blondin, Tensuan \& Fryer, I 963 ), but one of them (Montoye et al. 1965) shows that there is quite a marked increase in the number of lean people in the population after the age of about 60 years for men and about 67 for women. This could mean either that people become less fat after those ages or that only the less fat survive.

We need much more information on all aspects of nutrition in the elderlychanging body composition, protein requirements, requirements for calories, minerals and vitamins. Much work is needed and the problems become larger each year. It is surely the province of organizations with appropriate funds at their disposal, to encourage research into the elucidation of these problems. I see little evidence that such funds are being given for nutritional studies among the elderly -all the more strange since senescence is so obviously present in some of the controlling committees.

\title{
REFERENCES
}

Anderson, W. F. (1968). Proc. Nutr. Soc. 27, 185.

Bard, G. (1963). Archs phys. Med. Rehabil. 44, 368.

Behnke, A. R. (1963). Ann. N.Y. Acad. Sci. Body Composition, p. 450.

Bransby, E. R. \& Osborne, B. (1953). Br. $\mathcal{F}$. Nutr. 7, I60.

Chirico, A. M. \& Stunkard, A. J. (1960). New Engl. F. Med. 263, 935.

Durnin, J. V. G. A. (1966). Proc. Nutr. Soc. 25, 107.

Durnin, J. V. G. A., Blake, E. C. \& Brockway, J. M. (1957). Br. F. Nutr. Ir, 85.

Durnin, J. V. G. A., Blake, E. C., Brockway, J. M. \& Drury, E. A. (rg6r). Br. F. Nutr. r5, 499.

Durnin, J. V. G. A. \& Passmore, R. (1967). Energy, Work and Leisure, London: Heincmann Educational Books.

Exton-Smith, A. N. \& Stanton, B. R. (1965). Report of an Investigation into the Dietary of Elderly Wamen Living Alone. King Edward's Hospital Fund for London.

FAO (1957). F.A.O. nutr. Stud. no. 15.

Hirschberg, G. G. \& Ralston, H. J. (1965). Am. F. phys. Med. 44, 165.

Krzywicki, H. J. \& Chinn, K. S. K. (1967). Am. F. clin. Nutr. 20, 305.

Mayer, J. \& Bullen, B. (1964). Proc. int. Congr. Nutr. vi. Edinburgh, p. 27.

Molbech, S. (1966). In Physical Activity in Health and Disease. Oslo: Universitetsforlaget.

Montoye, H. J., Epstein, F. H. \& Kjelsberg, M. O. (1965). Am. F. clin. Nutr. 16, 417.

Müller, E. A. \& Hettinger, T. (1952). Z. Orthop. 8r, 525 .

National Research Council (1964). Publs natn. Res. Coun., Wash. no. I 466.

Parizkova, J. \& Eiselt, E. (I 966). Hum. Biol. 38, 35 I.

Young, C. M., Blondin, J., Tensuan, R. \& Fryer, J. H. (1963). Ann. N.Y. Acad. Sci. Body Composition, p. 589 .

\section{Protein status of the elderly}

By W. T. C. Berry, Ministry of Health, Elephant and Castle, London, $S E$ I

I propose to approach this question from the point of view of the epidemiologist and would say at once that I do not believe the necessary basic research has yet been done to enable the borderline between adequate and inadequate protein status 
of the elderly to be defined in terms of any parameters that might be useful to the epidemiologist.

Adequacy or inadequacy themselves involve some definition of malnutrition, and below I have used the definition accepted by the Panel on Nutrition of the Elderly (Ministry of Health, 1968 , in preparation) that it is 'A disturbance of form or function due to lack or excess of one or more nutrients'. This is a salutary definition because it means that evidence from biochemistry or from dietary study is not per se proof of malnutrition; the essential feature is that there should be an effect upon the individual. But, on the other hand, it is equally salutary to reflect that our means of detecting mild effects upon the individual are not very sensitive, and that certain aspects of senescence, which we regard as normal on little better evidence than that they are usual, could in fact be the cumulative effects of mild longstanding deficiency states.

The approach that I have followed today is by way of the accepted signs of protein deficiency, progressively in the direction of less and less certain evidence. The obvious first question to ask is whether there exists among the elderly in Britain oedema arising either out of too little protein in the diet, or secondary to undernutrition due to other causes; and the first place to look is in those sections of the community of elderly in whom it might be expected on general grounds to be most likely to occur.

Last year the Panel on Nutrition of the Elderly received evidence from twentysix consultant physicians to geriatric departments of hospitals up and down the country, on the incidence of signs of malnutrition observed in patients admitted to hospital under their care. Some of those who supplied evidence are, I think, here today and I take this opportunity of expressing the Panel's indebtedness. Though some of the patients (and it is I understand an increasing proportion) who are admitted to hospital are suffering from conditions that can be cured or eased, and are rehabilitated, for all too many, entry into hospital marks the end of independent life; in many instances this is postponed until all other means of carrying on have failed. For them this is, as it were, the moment of defeat. Obviously, therefore, this is a strongly selected sample.

With this in mind I considered the case records of II II unselected admissions to hospital of old people, sent in by the twenty-six geriatricians. Of these admissions, 274-approximately a quarter-had either generalized oedema or, much more commonly, oedema of the ankles. I hasten to add that this does not mean that they were suffering from protein deficiency. Oedema can occur for reasons ranging from varicose veins to acute heart failure, and the problem, when confronted with material from hospitals is to separate out what might be nutritional from that which is wholly non-nutritional. Obviously too there are cases in which the causes may be mixed; cardiac failure may cause oedema by itself, but with a protein deficiency this could be exacerbated; on the other hand, there may be a dietary deficiency of protein or more likely of calories arising because the subject is mentally deranged and has not eaten properly.

In the entire sample there were 503 patients diagnosed as suffering from con- 
fusion, depression or both, and the effect, upon their nutrition, may be judged by the fact that more than might have been expected were categorized as 'light' on the basis of their height to weight ratio. Among these twenty-one had oedema. (A further fourteen with oedema had a prime diagnosis of cerebral arteriosclerosis.) Such cases ought to be defined as suffering from primary malnutrition because even though there was a precipitating cause which was not nutritional in origin, it operated through the diet as opposed to exacerbating any effects of the diet as for example a malabsorption syndrome might. In addition to these subjects with mental disease there were sixteen individuals with oedema in association with some other nutritional disease and though these in most instances also had some non-nutritional disease they should I suggest be classed as probable primary malnutrition. Nevertheless a total of fifty-one out of this selected sample of nearly 1200 individuals is not much. The association with mental change is particularly important, and reflects a problem familiar to all welfare officers and geriatric consultants. Most cases of really severe malnutrition occur in individuals well known to the local Welfare Departments and have arisen despite all that could be done for them short of admission to hospital. The preponderance of persons who were 'light' among the mentally confused and depressed suggests that where oedema due to protein deficiency is encountered it is most likely to be a consequence of undernutrition.

To become oedematous requires a fairly severe degree of primary or secondary protein deficiency, and should be regarded as the tip, however small and occurring in however selected a population, of an iceberg. The next question is for what epidemiological evidence should one seek in assessing the prevalence of milder deficiencies of protein. Presumably a depletion of protein reserves is to be expected in long-standing moderate deficiency before vital functions break down, and it could well be that a shrinking of muscle, a microcytic anaemia without iron deficiency, and a moderate reduction in serum albumin but not globulin, might be found to precede more obvious signs such as oedema. In the surveys now being undertaken for the Ministry we hope to examine the interrelationships of these signs and of dietary intakes of protein. These interrelations do not seem to have been extensively studied, and opinions as to the value of serum proteins or serum albumin as an indicator of status differ, but Woodford-Williams, Alvarex, Webster, Landless \& Dixon (1964-5) reported little change in serum albumin (or other fractions) in fit elderly persons compared with younger people, although serum albumin fell with decreasing mobility. There was little relationship between serum proteins and a dietary score based on assessed intake of calories and protein; but the more marked the degree of undernutrition observed clinically the lower the serum protein. This is in agreement with the evidence on oedema already quoted which indicated that undernutrition is in practice more likely to lead to deficiency than is any absolute shortage of protein intake. E. Woodford-Williams (personal communication) also investigated albumin turnover in the elderly and found it to be within normal limits in undernourished elderly people. There appeared to be no reduction in the extravascular pool such as that reported by Picou \& Waterlow (1962) in cases of malnutrition in infancy, and suggested by them as the reason 
why the serum albumin and intravascular mass remain constant even in fairly advanced protein malnutrition (Madden \& Whipple, 1940; Whipple \& Madden, 1944).

Some of the theoretical aspects of the relationship between calorie intake and protein deficiency are to me I confess somewhat obscure. The level of energy intake which D. S. Miller \& P. R. Payne (personal communication) hold is necessary for elderly people to remain in positive nitrogen balance is well above the intakes of many apparently healthy elderly subjects in Britain today. Below such calorie levels Miller \& Payne hold that the amount and kind of protein consumed is of comparatively little importance; the individual cannot utilize his protein so as to maintain equilibrium. This view has to be reconciled with the fact that many, perhaps almost all, old people who are on low calorie intakes do not want more food. It could, of course, be that in the clderly a mild negative balance is a normal phenomenon and that calorie intakes are low because old people do not need that part of the energy supply which in younger subjects is used for anabolism. Rats fed initially on high and low nutritional planes by Widdowson \& Kennedy (1962) and then allowed to feed ad lib. on identical food for the rest of their lives lost weight as they grew older. A part of this weight loss was in the form of active tissue as opposed to fat and occurred to about the same extent, in terms of percentage of adult tissue lost in old age, among those on high and low planes of nutrition. Presumably therefore a mild negative nitrogen balance occurs naturally in rats despite an unrestricted energy intake. Whether a similar phenomenon occurs among elderly people who therefore eat comparatively small amounts of food is something on which I would not care to pontificate.

Apart from this problem of the calorie requirements of the old, any approach by way of dietary evidence at once poses the question of what are their requirements of protein. Swendseid \& Tuttle (1961), on the basis of their balance studies, concluded 'In men over $5^{\circ}$ years of age ... there is an indication of an increased requirement for essential nitrogen as compared with the needs for young men. The requirements for methionine and lysine appear to be at least double those of younger men'. On the other hand, Schulze (1954) held that elderly persons studied by him required $0.5 \mathrm{~g}$ protein per $\mathrm{kg}$ which was comparable to figures reported by others working with younger subjects under similar conditions, though he recommended intakes of $\mathrm{I}_{\mathrm{I}} \mathrm{O}-\mathrm{I}^{\circ} 5 \mathrm{~g}$ protein per $\mathrm{kg}$ in order to counter the effect of infections and injury without bringing forward any supporting evidence. Watkin (1964) held that elderly hypertensives on a rice-fruit diet achieved nitrogen equilibrium on about $0.35 \mathrm{~g}$ rice protein per I $\mathrm{kg}$ per day. Horwitt (1953) observed no difference over 3 months between old and young in achieving positive $\mathrm{N}$ balances on $6.5 \mathrm{~g} \mathrm{~N}$ daily; but he questioned the value of balance studies in determining theoretical requirements in old age because he noted that his subjects could go into negative balance on $6.5 \mathrm{~g}$ $\mathrm{N}$ daily, but later came into equilibrium. In reporting this, in effect, he voiced uncertainties that were reiterated in the Report on Requirements of Man for Protein (Ministry of Health, I964) about the interpretations of $\mathrm{N}$ balance studies in relation to the amount of labile protein deposition which is desirable in man. Horwitt 
reported no evidence that young people required less protein than old. But he and his colleagues (Horwitt, Rothwell \& Kark, 1953) noted that, on intakes of $6.5 \mathrm{~g} \mathrm{~N}$ daily, both young and old subjects developed signs of liver disfunction as indicated by excessive retention of injected bromsulphthalein, and abnormal levels of lactic and pyruvic acids after oral administration of glucose. Lysine, or methionine, or choline (or $10 \mathrm{~g}$ of lactalbumen) for 159 days, gave little or no ameliorative effect. Cure was achieved by $3 \circ \mathrm{g}$ of lactalbumen or a normal diet containing $70 \mathrm{~g}$ of protein daily. This finding by Horwitt et al. (1953) was, as far as I know, published only in Federation Proceedings, and therefore has not been subjected to the searching scrutiny which it might have received had it appeared in detail in one of the ordinary journals. But the protein intakes involved must have been of the order of $40 \mathrm{~g}$ daily, a figure which is not very different from Schulze's. Exton-Smith \& Stanton (1965) reported that among elderly women living alone there was a correlation between their health and the percentage of calories derived from protein. All except four of the subjects whose diet was 'better' than average enjoyed better health, whilst seventeen out of twenty-three subjects whose diet was worse than average had poorer health. Clinical criteria of good health are very difficult to define; the same problem is encountered in investigating 'poor general condition' in schoolchildren. This does not preclude the use of such an assessment in blind studies, and in this instance the assessment was made without knowledge of the dietary findings. In this connexion it is worth noting that the authors remark "This [correlation] is not to say that the diet must have affected the health. The reverse might equally be true.'

Protein intakes were in this study of the order of $\mathrm{I} g$ per $\mathrm{kg}$, averaging $57 \mathrm{~g}$ daily. There was no doubt a wide scatter of intakes expressed in these terms; but it is pertinent that the comparison in health is between the two halves of the population studied, and must therefore have been between those taking more, or less, than I $\mathrm{g}$ protein per $\mathrm{kg}$ weight. This is well above the amount involved in the studies of Horwitt et al. (1953) and of Schulze (1954) quoted above. A possibility that should not be ignored is that the elderly are--it has been postulated above-in a state of gradual catabolism which may be a physiological consequence of senescence, and they may find it more difficult to make good any catabolic response to injury following on minor illnesses and traumata which younger subjects might take in their stride. This would be in keeping with Schulze's views.

In conclusion, then, if we accept as final the evidence of balance studies, the protein requirement of the elderly (given adequate calories) is very roughly of the order of $40 \mathrm{~g} /$ day. If we feel dissatisfied with the evidence of balance studies and look for evidence of harm arising at higher intakes, we have to accept that so far this evidence is very nebulous and unconfirmed. Whether we shall obtain evidence on this issue from our own surveys rests with the gods.

I am indebted to the Chairman of the Panel on Nutrition of the Elderly, Dr W. Exton-Smith, for permission to study the evidence on hospital admissions mentioned above in order to set out the findings on oedema quoted in this paper. 
REFERENCES

Exton-Smith, A. N. \& Stanton, B. R. (1965). Report of an Investigation into the Dietary of Elderly Women Living Alone. King Edward's Hospital Fund for London.

Horwitt, M. K. (1953). F. Am. diet. Ass. 29, 443 .

Horwitt, M. K., Rothwell, W. S. \& Kark, R. M. (1953). Fedn Proc. Fedn Am. Socs exp. Biol. 12, 417.

Madden, S. C. \& Whipple, G. H. (1940). Physiol. Req. 20, r94.

Ministry of Health (1964). Rep. publ. Hlth med. Subj. no. II I.

Picou, D. \& Waterlow, J. C. (I962). Clin. Sci. 22, 3.

Schulze, W. (1954). Int. Congr. Geront. IIt. London, p. 122.

Swendseid, M. E. \& Tuttle, S. G. (1961). Publs. natn. Res. Coun., Wash. no. 843.

Watkin, D. M. (1964). In Mammalian Protein Metabolism. Vol. 2, Ch. I7. [H. N. Munro and J. B. Allison, editors.] New Yorls: Academic Press Inc.

Whipple, G. H. \& Madden, S. C. (I944). Medicine, Baltimore 23,2 I 5.

Widdowson, E. M. \& Kennedy, G. C. (1962). Proc. R. Soc. B r56, 96.

Woodford-Williams, Alvarex, A. S., Webster, D., Landless, B. \& Dixon, M. P. (1964-5). Gerontologia ro, 86 .

\section{Aspects of malnutrition in the elderly}

\section{By J. Andrews, West Middlesex Hospital, Isleworth}

When considering malnutrition in the elderly it must not be forgotten that this subject includes overnutrition and of course faulty nutrition. As has been pointed out by Professor Ferguson Anderson fat elderly men are a rarity. One reason for this is probably the high incidence of coronary artery disease found in the obese.

Dr Durnin has discussed energy requirements and Dr Berry proteins. Minerals will be considered later. I will, therefore, concentrate on general problems of malnutrition and topics connected with vitamin $\mathrm{C}$, folic acid and iron.

The following quotations from the British Medical Association (1950) Committee on Nutrition are of interest. Besides wishing to draw attention to "The urgent need for further extensive study of human nutritional requirements' the Committee recommended 'The speediest possible extension ... of meals delivery services for old people' and wished the government to 'promote the organisation of special catering departments in hospitals ... who should be responsible for feeding arrangements at all stages'.

A considerable amount of knowledge has been accumulated during the intervening 18 years with regard to the purchase of food but not with regard to the true intake of individuals, let alone the individual range of nutritional needs. Interesting investigations into the effect of deprivation of individual nutrients for long periods have been carried out, for example those of Crandon (1940) on experimental scurvy and Herbert (1962) on deprivation of folic acid. As far as I know there has been no work on experimental dietary iron deficiency in man.

With regard to the severity and prevalence of malnutrition in the elderly there are, in essence, three schools of thought. Dr Geoffrey Taylor (I966) stated that he found 'classical signs of vitamin deficiences and malnutrition in patients of all ages and classes in Britain' but this is unproven. At the other end of the scale it is suggested 